\title{
PENGEMBANGAN PERANGKAT PEMBELAJARAN BERBASIS INKUIRI TERBIMBING UNTUK MENINGKATKAN KREATIVITAS ILMIAH SISWA SMP
}

\author{
Masruroh'), Wahono Widodo' $^{2)}$, M. Thamrin Hidayat ${ }^{3)}$ \\ ${ }^{1)}$ Mahasiswa Program Pascasarjana, Program Studi Pendidikan Sains, Universitas Negeri Surabaya \\ 2), 3)Dosen Pascasarjana Prodi Pendidikan Sains Universitas Negeri Surabaya \\ E-mail: ismi_masruroh@yahoo.com
}

\begin{abstract}
This research is aimed to present brief description about development of guided inquiry learning material to increase students' scientific creativity in the aspect of designing an experiment. The development of learning material was done by using 4D model from Thiagarajan (1974). The component of learning material that was developed such as lesson plan, student worksheet, hand out, and assessment sheet. There were 3 experts and 12 students from $7^{\text {th }}$ grade at SMPN 6 Surabaya participated in development testing of learning material. Data was obtained from validation and response sheet. Construct validation and external validation were obtained from this research. The results showed that learning material's component is valid and reliable.
\end{abstract}

Keywords: Learning Material, Guided Inquiry, Scientific Creativity

Abstrak: Penelitian ini bertujuan untuk memberikan gambaran umum hasil pengembangan perangkat pembelajaran berbasis inkuiri terbimbing untuk meningkatkan kreativitas ilmiah siswa SMP dalam aspek merancang kegiatan penyelidikan. Pengembangan perangkat dilakukan menggunakan model 4D dari Thiagarajan (1974). Perangkat yang dikembangkan meliputi RPP, LKS, Handout, dan Lembar penilaian. Sebanyak 3 pakar dan 12 siswa kelas VII SMPN 6 Surabaya berpartisipasi dalam uji coba terbatas perangkat. Data didapatkan dari lembar validasi dan lembar respon menggunakan teknik angket. Data yang didapatkan berupa data validitas konstruk dan validitas eksternal. Hasil penelitian menunjukkan komponen perangkat yang dikembangkan sudah valid dan reliabel.

Kata Kunci: Perangkat Pembeajaran, Inkuiri Terbimbing, Kreativitas Ilmiah

\section{PENDAHULUAN}

Berdasarkan polling yang diadakan pada Tahun 2007 oleh Partnership for $21^{\text {st }}$ Century Skills, 80\% respondennya menyatakan bahwa kemampuan yang diperlukan siswa untuk dipelajari saat ini berbeda dengan kemampuan yang harus mereka pelajari 20 tahun yang lalu (Bob, 2008). Salah satu kemampuan tersebut adalah kreativitas. Berkembangnya teknologi dan inovasi yang memberikan tantangan baru dalam kehidupan menjadikan persaingan dunia kerja menjadi semakin kompetitif. Oleh karenanya, siswa perlu dibekali dengan keterampilan Abad ke-21 yang salah satunya adalah kemampuan berpikir kreatif agar potensi kreativitas mereka dapat dioptimalkan sehingga mereka benar-benar siap menghadapi tantangan di Abad ke-21.

Kreativitas ilmiah termasuk kreativitas yang spesifik (specific domain creativity) (Mohamed, 2006), sehingga kreativitas ilmiah tidak seperti kreativitas secara umum (general creativity). Kreativitas ilmiah berkaitan dengan pengetahuan dan keterampilan proses (Muhamed, 2006; Hu dan Adey, 2002). Jo (2009) menambahkan bahwa kreativitas imiah juga berkaitan dengan pemahaman terhadap hakikat IPA dan sikap terhadap IPA. Jo (2009) mendefinisikan kreativitas ilmiah atau kreativitas dalam IPA sebagai ide, proses, tingkah laku, dan produk yang memiliki kebaruan dan kegunaan dalam IPA. Hu dan Adey (2002) mendefinisikan kreativitas ilmiah sebagai kemampuan intelektual untuk menghasilkan atau memiliki potensi untuk menghasilkan sesuatu yang baru dan memiliki nilai sosial dan personal yang didesain dengan tujuan tertentu menggunakan informasi yang diberikan. Muhamed (2006) mendefinisikan kreativitas ilmiah sebagai kerja ilmiah menggunakan berbagai keterampilan proses dengan memiliki pengetahuan yang memadai, dan kemampuan untuk menemukan dan menyelesaikan permasalahan dengan cara yang unik dan layak.

Berdasarkan beberapa definisi yang telah dikemukakan di atas, kreativitas ilmiah dapat didefinisikan sebagai hasil kemampuan berpikir yang dapat dilihat dari produk dihasilkan maupun proses yang digunakan untuk memecahkan masalah ilmiah yang memiliki nilai kebaruan (originality) dan kesesuaian (appropriateness).

Kreativitas ilmiah muncul selama proses penyelesaian rangkaian tugas-tugas penyelidikan 
(Kocabas, 1993). Kreativitas ilmiah menurut Kocabas (1993) dapat ditelusuri melalui motivasi untuk melaksanakan suatu penyelidikan ilmiah, kemampuan untuk menyusun suatu rumusan masalah dalam suatu ilmu pengetahuan, kemampuan untuk menentukan suatu lingkup penyelidikan yang komprehensif untuk penyelesaian masalah ilmiah, kemampuan untuk merangkai atau menginduksi dan menerapkan kumpulan cara untuk menyelesaikan suatu permasalahan melalui kegiatan penyelidikan, dan kesabaran dan stamina untuk melakukan suatu penelitian yang melelahkan untuk mendapatkan penyelesaian masalah melalui lingkup penyelidikan yang terstruktur.

Beberapa negara di dunia telah mengembangkan pendekatan baru dalam pendidikan untuk mempersiapkan generasi mereka dengan keterampilanketerampilan yang dibutuhkan di Abad ke-21 yang salah satunya adalah kreativitas. Berangkat dari pandangan Aktamis dan Ergin (2008), Karkockiene (2005), dan Lin (2011) bahwa kreativitas merupakan sesuatu yang dapat dikembangkan melalui kegiatan pembelajaran dan semua individu memiliki potensi untuk menjadi kreatif, maka dikembangkanlah beberapa pendekatan untuk mengembangkan kreativitas dalam pendidikan. Reformasi kurikulum telah dilakukan dan kreativitas masuk ke dalam kebijakan pendidikan di negara-negara barat seperti Amerika Serikat, Inggris, Perancis, Jerman, Swedia, dan Australia (Feldman \& Benjamin, 2006; Craft, 2005; Saheen, 2010; dalam Lin, 2011). Beberapa negara di Asia seperti Cina, Hong Kong, Jepang, Korea Selatan, Taiwan, dan Singapura juga merespon perubahan tantangan dalam dunia pendidikan dengan mereformasi kurikulum pendidikannya dengan menekankan pada pengembangan kreativitas (Choe, 2006; Saheen, 2010; dalam Lin, 2011).

Pemerintah Indonesia juga merespon hal tersebut dengan diterapkannya kurikulum yang diberi nama Kurikulum 2013. Kurikulum ini diterapkan sebagai salah satu upaya untuk menanggapi perubahan global dan mempersiapkan generasinya untuk menghadapi tantangan di Abad ke-21. Tujuan Kurikulum 2013 yang termuat dalam Peraturan Menteri Pendidikan dan Kebudayaan No. 58 Tahun 2014 salah satunya adalah mempersiapkan manusia Indonesia agar memiliki kemampuan hidup sebagai pribadi dan warga negara yang kreatif sehingga mampu berkontribusi pada kehidupan bermasyarakat, berbangsa, bernegara, dan peradaban dunia.

Pendidikan IPA dalam Kurikulum 2013 diarahkan pada pembelajaran berbasis penemuan (inquiry) dengan salah satunya menerapkan pendekatan keterampilan proses. Barrow (2010) menjelaskan seperti apa yang diungkapkan Slavin (2012) bahwa di dalam inkuiri terdapat beberapa strategi yang dapat digunakan untuk memfasilitasi kreativitas, antara lain siswa diberikan kesempatan untuk merancang penyelidikannya sendiri berdasarkan rumusan masalah yang dikemukakan, bekerja dalam kelompok kecil saat merancang langkah kerja, dan berbagi (mengkomunikasikan) hasil kerjanya dengan teman sebayanya.

Pendidikan IPA dengan pembelajaran berbasis penemuan (inquiry) tersebut diharapkan dapat membantu tercapainya salah satu tujuan pelajaran IPA seperti yang tertulis dalam Peraturan Menteri Pendidikan dan Kebudayaan No. 58 Tahun 2014 yaitu agar siswa dapat menunjukkan kreativitas dalam aktivitas sehari-hari sebagai wujud implementasi sikap dalam melakukan pengamatan, percobaan, dan diskusi. Selain itu diharapkan melalui pelajaran IPA siswa mampu mengembangkan keterampilan proses melalui pengalaman untuk menggunakan, mengajukan dan menguji hipotesis melalui suatu percobaan, sekaligus merancang dan merakit instrumen percobaan, juga mengumpulkan, mengolah dan menafsirkan data, serta mengkomunikasikan hasil percobaan baik secara lisan maupun tulisan.

Pemerintah sudah menyiapkan beberapa komponen perangkat pembelajaran untuk menunjang pelaksanaan pembelajaran IPA dengan Kurikulum 2013, di antaranya adalah silabus, Buku Pegangan Guru yang di dalamnya terdapat petunjuk pelaksanaan pembelajaran secara garis besar beserta format penilaiannya, dan Buku Siswa. Buku Siswa yang sudah dibuat khusus untuk Kurikulum 2013 yang disediakan oleh Pemerintah sudah memiliki fitur yang memungkinkan adanya pengembangan keterampilan proses, salah satunya adalah fitur "Ayo Kita Lakukan" yang mengajak siswa melakukan kegiatan praktikum sehingga mendorong siswa untuk aktif dalam pembelajaran dan meningkatkan rasa ingin tahu siswa.

Perangkat pembelajaran yang sudah disiapkan oleh pemerintah tersebut belum dapat mengoptimalkan kreativitas ilmiah meskipun sudah terdapat fitur "Ayo Kita Lakukan" yang didesain untuk pengembangan keterampilan proses. Fitur ini masih tampak seperti "buku resep". Siswa hanya mengikuti langkah kerja yang disediakan pada fitur tersebut. Belum ada fitur yang mengoptimalkan kreativitas ilmiah melalui kegiatan perancangan sendiri kegiatan penyelidikan oleh siswa. Buku Siswa ini perlu dilengkapi dengan Lembar Kerja Siswa (LKS) yang berisi kegiatan yang dapat mengembangkan kreativitas ilmiah di mana siswa diberikan kesempatan untuk dapat merancang penyelidikannya sendiri melalui kegiatan membuat rumusan masalah, membuat hipotesis, mengontrol variabel, memilih alat dan bahan, menentukan langkah kerja, menggambar rancangan kegiatan penyelidikan, membuat tabel data hasil penyelidikan, dan memberikan alternatif alat dan bahan yang diperlukan dalam kegiatan penyelidikan. 
Pengembangan perangkat pembelajaran berbasis inkuiri terbimbing yang disesuaikan dengan format perangkat pembelajaran untuk kurikulum 2013 yang terdapat pada Permendikbud Nomor 58 Tahun 2014 tentang Kurikulum 2013 SMP/MTs ini ditujukan untuk meningkatkan kreativitas ilmiah siswa SMP. Hasil pengembangan perangkat ini diharapkan dapat membantu pelaksanaan pembelajaran IPA untuk meningkatkan kreativitas ilmiah siswa.

Rencana pelaksanaan pembelajaran merupakan panduan langkah-langkah mengajar bagi guru yang disusun sebelum pembelajaran. Rencana pelaksanaan pembelajaran disusun untuk 5 kali pertemuan, 2 kali pertemuan dengan alokasi waktu masing-masing $3 \times 40$ menit dan 3 kali pertemuan dengan alokasi waktu masing-masing $2 \times 40$ menit. RPP yang dikembangkan sebagai panduan dalam menerapkan pembelajaran berbasis inkuiri terbimbing sehingga dalam kegiatan pembelajarannya memuat fase-fase pembelajaran berbasis inkuiri terbimbing. Fase pembelajaran inkuiri menurut Arends (2012) antara lain 1) Menarik perhatian siswa dan menjelaskan proses inkuiri (Apersepsi); 2) Menampilkan masalah inkuiri atau fenomena; 3) Menyusun hipotesis untuk menjelaskan masalah atau fenomena; 4) Mendorong siswa untuk mengumpulkan data untuk menguji hipotesis; 5) Menyusun penjelasan dan/atau simpulan; dan 6) Merefleksi permasalahan dan proses berpikir yang digunakan dalam inkuiri.

Lembar kegiatan siswa merupakan panduan untuk siswa yang digunakan untuk melakukan kegiatan penyelidikan. Fitur utama dalam LKS yang dikembangkan adalah "Desain sendiri kegiatan penyelidikanmu". Siswa diberikan suatu permasalahan yang dekat dengan kehidupan sehari-hari dan mereka diminta untuk mengumpulkan data melalui kegiatan penyelidikan yang mereka desain sendiri untuk menyelesaikan permasalahan tersebut. LKS juga memuat komponen alat dan bahan yang tersedia, di sini dituliskan variasi alat dan bahan beserta ukuran yang dapat digunakan sehingga siswa dapat memilih alat dan bahan beserta variasi ukurannya dalam desain kegiatan penyelidikan yang dibuatnya. Fitur dalm LKS ini diharapkan dapat digunakan untuk meningkatkan kreativitas ilmiah siswa terutama dalam merancang suatu percobaan.

Handout siswa merupakan buku pendamping panduan belajar siswa yang digunakan dalam proses belajar mengajar. Handout ini berisi ringkasan materi pelajaran yang akan dipelajari siswa beserta penerapannya dalam kehidupan sehari-hari. Handout ini juga dilengkapi fitur yang menunjang kreativitas ilmiah siswa seperti fitur "Mari Bermain". Pada fitur "Mari Bermain" siswa diberikan permasalahan dan link website yang menyediakan game lab virtual, sehingga siswa dapat mencoba menyelesaikan permasalahan melalui lab virtual yang disediakan dalam website tersebut. Website yang digunakan adalah http://www.sciencekids.co.nz. Selain itu juga terdapat fitur "Mari Refleksi Diri" yang mengajak siswa untuk memaknai pembelajaran dan dihubungkan dengan sikap spiritual dan sosial mereka.

Instrumen penilaian kreativitas ilmiah dikembangkan berdasarkan indikator kreativitas ilmiah dalam hal merancang kegiatan penyelidikan yang diadaptasi dari Kocabas (1993) yang meliputi: (1) merumuskan masalah; (2) membuat hipotesis; (3) menentukan lingkup penyelidikan (menentukan variabel dan mendefinisikannya secara operasional); (4) menentukan alat dan bahan; (5) menentukan langkah penyelidikan; (6) menggambar rancangan kegiatan penyelidikan; (7) membuat tabel data hasil penyelidikan; dan (8) memberikan alternatif alat dan bahan yang dinilai berdasarkan karakteristik kreativitas yaitu fluency, flexibility, originality, dan appropriateness.

\section{METODE PENELITIAN}

Jenis penelitian ini adalah penelitian pengembangan dengan menggunakan model 4-D (Thiagarajan, 1974). Dalam artikel ini hanya akan dijelaskan gambaran umum hasil penelitian pengembangan pada tahapan uji coba terbatas (development testing).

Instrumen dalam penelitian ini adalah lembar validasi dan lembar respon siswa. Data yang didapatkan berupa penilaian validasi dari para ahli dan data kreativitas imiah siswa yang akan digunakan untuk analisis validitas konstruk dan ekternal.

Data hasil validasi dianalisis dengan menghitung rata-rata hasil validasi dari tiga pakar. Data tersebut digunakan untuk menilai kelayakan perangkat sesuai kriteria penilaian perangkat pembelajaran pada Tabel 1.

Tabel 1. Kriteria Penilaian Perangkat Pembelajaran

\begin{tabular}{|c|l|}
\hline Interval Skor & \multicolumn{1}{|c|}{ Keterangan } \\
\hline $0-1,00$ & Tidak baik/ Tidak layak \\
\hline $1,05-1,75$ & Kurang baik/ Kurang layak \\
\hline $1,80-2,50$ & Cukup baik/ Cukup layak \\
\hline $2,55-3,25$ & Baik/ Layak \\
\hline $3,30-4,00$ & Sangat baik/ Sangat layak \\
\hline
\end{tabular}

(diadaptasi dari Ratumanan dan Laurens, 2011)

Perangkat dapat dikatakan valid dengan skor minimal 1,80 atau dengan kriteria cukup baik atau cukup layak. Instrumen kreativitas ilmiah juga divalidasi menggunakan validitas empiris menggunakan rumus $r$ product moment dengan angka kasar sebagai berikut:

$$
\begin{aligned}
& r_{x y}=\frac{N \Sigma X Y-[\Sigma X)(\Sigma Y)}{\left.\sqrt{ } N \Sigma X^{2}-(\Sigma X)^{2}\right]\left\{N \Sigma Y^{2}-(\Sigma Y)^{2}\right\}} \text { (Arikunto, 2010) } \\
& \text { Dengan, } \\
& r_{x y}=\text { koefisien korelasi antara variabel } \mathrm{X} \text { dan } \mathrm{Y}
\end{aligned}
$$




$$
\begin{aligned}
& X=\text { nilai data kelompok variable } \mathrm{X} \\
& Y=\text { nilai data kelompok variable } \mathrm{Y} \\
& N=\text { banyak data }
\end{aligned}
$$

Harga perhitungan korelasi di atas dikonsultasikan dengan kriteria validitas pada Tabel 2 untuk menentukan tingkat validitas.

Tabel 2. Kriteria Validitas Instrumen

\begin{tabular}{|c|c|}
\hline Koefisien Validitas & Interpretasi \\
\hline $\mathrm{r} \leq 0,00$ & Tidak valid \\
\hline $0,00<\mathrm{r} \leq 0,20$ & Validitas sangat rendah \\
\hline $0,20<\mathrm{r} \leq 0,40$ & Validitas rendah \\
\hline $0,40<\mathrm{r} \leq 0,60$ & Validitas sedang \\
\hline $0,60<\mathrm{r} \leq 0,80$ & Validitas tinggi \\
\hline $0,800<\mathrm{r} \leq 1,00$ & Validitas sangat tinggi \\
\hline
\end{tabular}

Reliabilitas butir penilaian kreativitas ilmiah dengan bentuk uraian dihitung menggunakan rumus Chronbach Alpha berikut:

$$
r_{11}=\left(\frac{k}{k-1}\right)\left(1-\frac{\Sigma o_{b}^{2}}{\sigma_{t}^{2}}\right)
$$

(Arikunto, 2010)

Dengan,

$r_{11}=$ reliabilitas instrumen

$k \quad=$ banyaknya butir pertanyaan

$\Sigma \sigma_{b}^{2}=$ Jumlah varians butir

$\sigma_{t}^{2}=$ Varians total

Hasil perhitungan reliabilitas kemudian dikonsultasikan dengan tabel $r$ product moment. Instrumen dikatakan reliabel jika $r_{l l}$ lebih besar daripada rtabel dengan taraf signifikansi 0,05 dan $\mathrm{N}=12$. Harga perhitungan korelasi di atas dikonsultasikan dengan kriteria reliabilitas pada Tabel 3 untuk menentukan tingkat reliabilitas.

Tabel 3. Kriteria Reliabilitas Instrumen

\begin{tabular}{|l|l|}
\hline $\begin{array}{c}\text { Koefisien } \\
\text { Reliabilitas }\end{array}$ & \multicolumn{1}{|c|}{ Interpretasi } \\
\hline $\mathrm{r}<0,40$ & Reliabilitas rendah \\
\hline $0,40 \leq \mathrm{r}<0,80$ & Reliabilitas sedang \\
\hline $0,80 \leq \mathrm{r}$ & Reliabilitas tinggi \\
\hline
\end{tabular}

(Ratumanan dan Laurens, 2011)

Butir penilaian kreativitas ilmiah diuji sensitivitasnya menggunakan modifikasi rumus sensitivitas Gronlund untuk soal uraian sebagai berikut:

$$
\begin{aligned}
& \mathrm{S}=\Sigma S_{S e S}-\Sigma S_{S e b} \\
& N\left(S_{\text {maks }}-S_{\text {min }}\right) \\
& \text { (diadaptasi dari Ratumanan dan Laurens, 2011) } \\
& \text { Dengan, } \\
& S \quad=\text { Indeks sensitivitas butir soal }
\end{aligned}
$$

$$
\begin{array}{ll}
\Sigma S_{\text {ses }}= & \begin{array}{l}
\text { Jumlah skor subjek pada butir tertentu } \\
\text { sesudah pembelajaran }
\end{array} \\
\Sigma S_{\text {seb }}= & \text { Jumlah skor subjek pada butir tertentu } \\
& \text { sebelum pembelajaran } \\
N & =\text { Jumlah subjek } \\
S_{\text {maks }}= & \text { Skor maksimal butir tertentu } \\
S_{\text {min }}= & \text { Skor minimal butir tertentu }
\end{array}
$$

Harga S mulai dari 0 - 1,00. Harga 0 diinterpretasikan butir tes tersebut tidak sensitif, sedangkan harga sensitivitas 1 menunjukkan butir tes tersebut sangat sensitif. Menurut Aiken (1988), butir tes dengan harga sensitivitas $\geq 0,30$ tergolong sebagai butir tes yang sensitif.

\section{HASIL PENELITIAN DAN DISKUSI}

Berdasarkan penilaian dari para pakar didapatkan penilaian validitas komponen perangkat yang ditunjukkan pada Gambar 1.

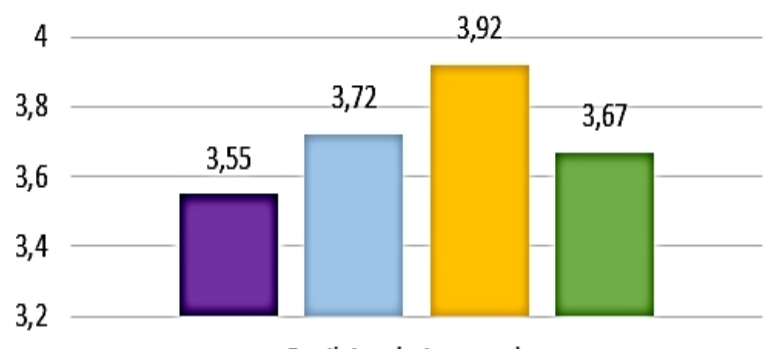

Penilaian dari para pakar

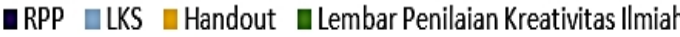

Gambar 1. Penilaian validitas komponen perangkat dari para pakar

Gambar 1 menunjukkan bahwa RPP yang dikembangkan mendapat rata-rata penilaian dari pakar sebesar 3,55 sehingga RPP yang dikembangkan tergolong sangat baik. Hal ini dapat terjadi karena RPP yang dikembangkan sudah mengikuti pedoman pembuatan RPP dalam Permendikbud Nomor 58 Tahun 2014 tentang Kurikulum 2013 SMP/ MTs.

Rencana Pelaksanaan Pembelajaran (RPP) berbasis inkuiri terbimbing ini diharapkan nantinya dapat digunakan sebagai panduan dalam menyampaikan pembelajaran untuk memfasilitasi siswa dalam mengembangkan kreativitas ilmiah. Ha tersebut didukung oleh Muhamed (2006) yang menyatakan bahwa kreativitas ilmiah siswa berhubungan dengan pengetahuan ilmiah dan keterampilan yang dikembangkan guru di sekolah. Keterampilan yang dimaksud adalah keterampilan proses. Keterampilan proses ini digunakan sebagai pendekatan untuk menyelesaikan permasalahan secara kreatif. Hal ini sesuai dengan pendapat Yager dan Akçay (dalam Ergul, Simsekli, Calis, Ozdilek, Gocmencelebi, dan Sanli, 2011) yang menyatakan inkuiri sebagai pendekatan 
dalam pembelajaran tentang bagaimana ilmuwan bekerja yang merupakan metode pembelajaran yang sangat efektif untuk membantu siswa dalam memahami konsep dan menggunakan keterampilan proses.Gambar 1 juga menunjukkan hasil penilaian validator terhadap LKS dengan rata-rata penilaian sebesar 3,72 sehingga LKS yang dikembangkan tergolong sangat baik. Hal ini dapat terjadi karena LKS yang dikembangkan sudah mengikuti kriteria kelayakan menurut BSNP (2014) yang meliputi kelayakan isi, penyajian, dan bahasa, dan sudah memperhatikan tahapan dalam pembelajaran inkuiri terbimbing seperti yang dijelaskan oleh Arends (2012) sehingga LKS yang dikembangkan dapat memuat karakteristik siswa dalam pembelajaran inkuiri.

Lembar Kerja Siswa yang dikembangkan juga sudah memuat fitur yang mendukung pengembangan kreativitas imiah siswa. Fitur tersebut adalah "Desain sendiri kegiatan penyelidikanmu". Siswa diberikan suatu permasalahan yang dekat dengan kehidupan sehari-hari dan mereka diminta untuk mengumpulkan data melalui kegiatan penyelidikan yang mereka desain sendiri untuk menyelesaikan permasalahan tersebut. LKS juga memuat komponen alat dan bahan yang tersedia, di sini dituliskan variasi alat dan bahan beserta ukuran yang dapat digunakan sehingga siswa dapat memilih alat dan bahan beserta variasi ukurannya dalam desain kegiatan penyelidikan yang dibuatnya, dengan demikian rancangan kegiatan penyelidikan yang dibuat siswa dapat berbeda dengan siswa lainnya. Berdasarkan uraian di atas dapat dikatakan LKS yang dikembangkan dapat digunakan untuk memfasilitasi pengembangan kreativitas ilmiah siswa. Contoh LKS yang dikembangkan dapat dilihat pada Gambar 2.

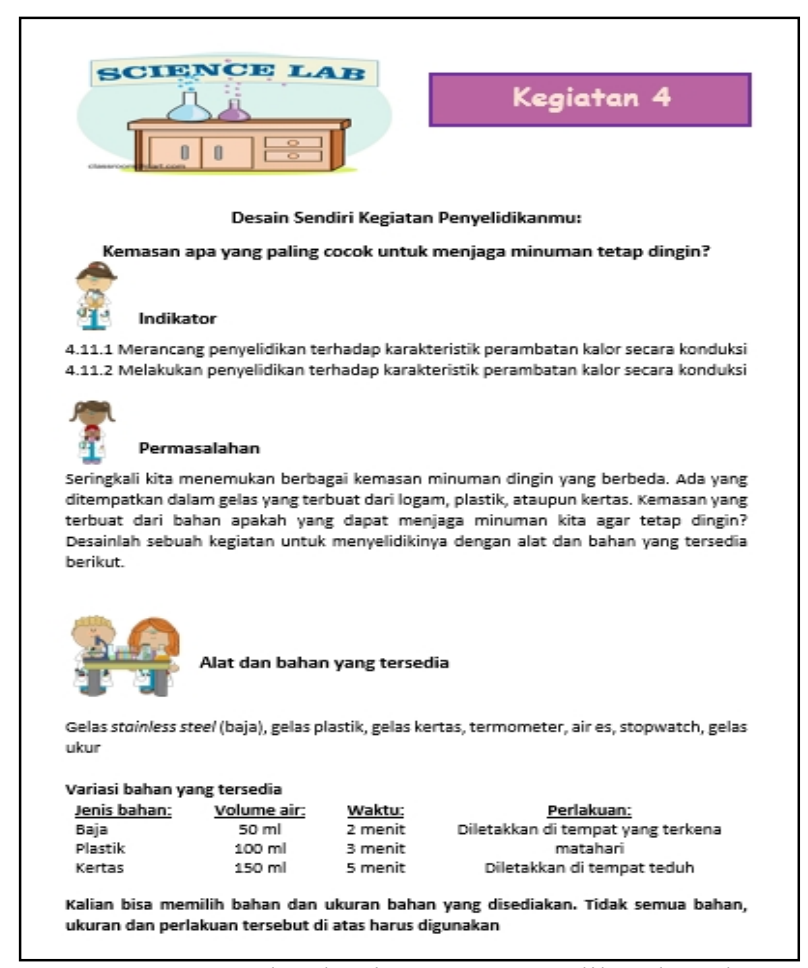

Gambar 2. Contoh sebagian LKS yang dikembangkan
Gambar 1 juga menunjukkan hasil penilaian pakar terhadap handout dengan rata-rata penilaian sebesar 3,92 sehingga handout yang dikembangkan tergolong sangat baik. Hal ini dapat terjadi karena handout yang dikembangkan sudah memenuhi kriteria kelayakan menurut BSNP (2014) yang meliputi kelayakan isi, penyajian, dan bahasa, dan sudah memperhatikan tahapan dalam pembelajaran inkuiri terbimbing seperti yang dijelaskan oleh Arends (2012) dan juga disertai dengan fitur-fitur yang menunjang kreativitas ilmiah siswa seperti fitur "Mari Bermain". Fitur "Mari Bermain" memberikan siswa kesempatan untukmenyelesaikan permasalahan dari link website yang menyediakan game lab virtual, sehingga siswa dapat mencoba menyelesaikan permasalahan melalui lab virtual yang disediakan dalam website tersebut. Selain itu juga terdapat fitur "Mari Refleksi Diri" yang mengajak siswa untuk memaknai pembelajaran dan dihubungkan dengan sikap spiritual dan sosial. Handout yang dikembangkan ditujukan untuk membantu siswa dalam memahami materi kalor yang diajarkan dan diharapkan dapat menunjang pengembangan kreativitas ilmiah siswa. Hal ini sesuai dengan pendapat Muhamed (2006) yang menyatakan bahwa kreativitas ilmiah siswa berhubungan dengan pengetahuan ilmiah dan keterampilan yang dikembangkan guru di sekolah.

Berdasarkan hasil uji coba terbatas didapatkan data sensitivitas, validitas eksternal, dan reliabilitas butir penilaian kreativitas ilmiah. Hasil perhitungan sensitivitas butir penilaian kreativitas ilmiah ditunjukkan pada Gambar 3.

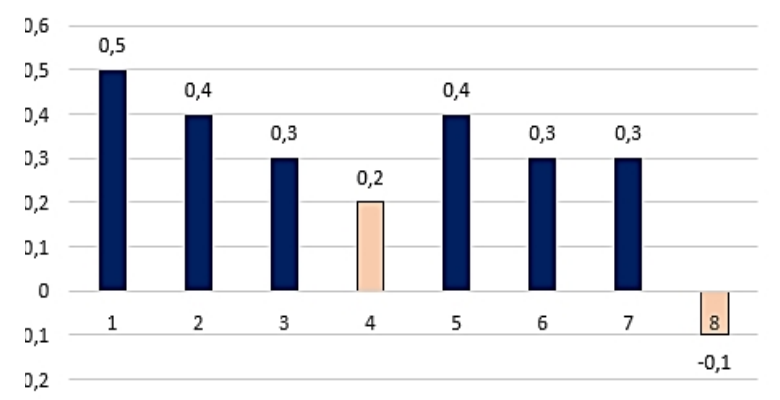

Gambar 3. Perhitungan Sensitivitas Butir Penilaian Kreativitas Ilmiah

Berdasarkan hasil perhitungan sensitivitas instrumen penilaian kreativitas imiah pada Gambar 3 terdapat 2 butir instrumen yang kurang sensitif dengan indeks sensitivitas kurang dari 0,3 yaitu butir keempat dan kedelapan. Butir keempat adalah butir untuk indikator menentukan alat dan bahan dalam rancangan penyelidikan. Indeks sensitivitas butir ini sebesar 0,2, hal ini dapat terjadi karena sebagian besar siswa sudah dapat menentukan alat dan bahan yang diperlukan dalam rancangan penyelidikan pada saat pretest sehingga peningkatan skor pada aspek ini saat posttest tidak terlalu besar. Sedangkan butir kedelapan adalah butir 
untuk indikator memberikan alternatif alat dan bahan pengganti dalam rancangan kegiatan penyelidikan. Indeks sensitivitas untuk butir ini 0 . Hal ini dapat terjadi karena sebagian besar siswa sudah dapat menentukan alternatif alat dan bahan yang diperlukan dalam rancangan penyelidikan pada saat pretest sehingga peningkatan skor pada aspek ini saat posttest tidak terlalu besar.

Berdasarkan uraian di atas, butir soal nomor 4 dan 8 tidak digunakan. Butir soal nomor 4 adalah butir soal untuk indikator menentukan alat dan bahan dalam rancangan penyelidikan, sehingga indikator ini tidak dapat dipertahankan karena butir soal yang mewakilinya kurang sensitif. Butir soal nomor 8 dalah butir soal untuk indikator memberikan alternatif alat dan bahan pengganti dalam rancangan kegiatan penyelidikan, sehingga indikator ini tidak dapat dipertahankan karena butir soal yang mewakilinya tidak sensitif. Indikator yang dipakai adalah merumuskan masalah, membuat hipotesis, menentukan lingkup penyelidikan (menentukan variabel dan mendefinisikannya secara operasional), menentukan langkah penyelidikan, menggambar rancangan kegiatan penyelidikan, dan membuat tabel data hasil penyelidikan, sehingga karakteristik kreativitas yang muncul hanya originality dan appropriateness.

Berdasarkan hasil perhitungan validitas lembar penilaian kreativitas ilmiah didapatkan $r_{x y}$ sebesar 0,713 sehingga lembar penilaian kreativitas ilmiah dinyatakan valid dengan tingkat validitas tinggi dan dari hasil perhitungan didapatkan nilai $r_{11}$ sebesar 0,698 dan $r_{\text {tabel }}$ sebesar 0,576 sehingga instrumen penilaian kreativitas ilmiah dinyatakan reliabel dengan tingkat reliabilitas sedang.

Instrumen penilaian kreativitas ilmiah sebagian besar sudah dikembangkan berdasarkan indikator kreativitas ilmiah dalam hal merancang kegiatan penyelidikan seperti yang dijelaskan oleh Kocabas (1993) yang meliputi: (1) merumuskan masalah; (2) membuat hipotesis; (3) menentukan lingkup penyelidikan (menentukan variabel dan mendefinisikannya secara operasional); (4) menentukan langkah penyelidikan; (5) menggambar rancangan kegiatan penyelidikan; dan (6) membuat tabel data hasil penyelidikan yang dinilai berdasarkan karakteristik kreativitas yang muncul yaitu originality dan appropriateness. Berdasarkan uraian di atas, komponen perangkat pembelajaran berbasis inkuiri terbimbing yang meliputi RPP, LKS, Handout, dan Lembar penilaian kreativitas ilmiah dapat dikatakan valid dan reliabel.

\section{KESIMPULAN}

A. Simpulan

Hasil penelitian menunjukkan komponen perangkat yang dikembangkan yang meliputi RPP, LKS,
Handout, dan Lembar penilaian kreativitas ilmiah dapat dikatakan valid dan reliabel.

\section{B. Saran}

Butir penilaian kreativitas ilmiah yang tidak sensitif masih memerlukan perbaikan agar dalam penelitian selanjutnya butir ini dapat dipakai dan indikator kreativitas ilmiah tidak berkurang sehingga aspek fluency dan flexibility dapat dimunculkan untuk mendukung penilaian kreativitas ilmiah siswa.

\section{DAFTAR PUSTAKA}

Aiken, L. H. (1988). Psychological Testing and. Assessment $6^{\text {th }}$ Edition. Boston: Allyn and Bacon, Inc.

Aktamis, H., dan Ergin, O. (2008). The Effect of Scientific Process Skills Education on Students' Scientific Creativity, Science Attitudes and Academic Achievement. AsiaPasific Forum on Science Learning and Teaching.

Arends, R. I. (2012). Learning to Teach. New York: The McGraw-Hill Companies, Inc.

Arikunto, S. (2010). Prosedur Penelitian: Suatu Pendekatan Praktik. Jakarta: Rineka Cipta.

Barrow, L. H. (2010). Encouraging Creativity with Scientific Inquiry. Creative Education , 1-6.

Bob, Regan. (2008). Why we Need to Teach $21^{\text {st }}$ Century Skills-And How to Do It. Multimedia \& Internet @School, 15(4): $10-13$.

BSNP. (2014, 5 28). Instrumen Penilaian Buku Teks Pelajaran 2014. Diambil kembali dari Badan Standar Nasional Pendidikan: http://bsnp-indonesia.org/id/?p=1340

Direktorat Jendral Managemen Pendidikan Dasar dan Menengah, Kemendikbud. (2014). Peraturan Menteri Pendidikan dan Kebudayaan Nomor 58 Tahun 2014 tentang Kurikulum 2013 SMP/MTs. Jakarta: Kemendikbud.

Ergul, R., Yeter Simsekli, Sevgul Calis, Zehra Odzilek, Sirin Gocmencelebi, dan Meral Sanli. (2011). The Effects of Inquiry-Based science Teaching on Elementary school Students' science Process Skills and Science Attitudes. Bulgarian Journal of Science and Education Policy, 48-68.

Hu, W., \& Adey, P. (2002). A Scientific Creativity Test for Secondary School Students. International Journal of Science Education , 389-403.

Jo, S. M. (2009). A Study of Korean Students' Creativity in Science Using Structural Equation Modeling (Unpublished doctoral dissertation). The University of Arizona.

Karkockiene, D. (2005). Creativity: Can It be Trained?

A Scientific Educology of Creativity. $c d$ -

International Journal of Educology, 51-58. 
Kocabas, S. (1993). Elements of Scientific Creativity. Technical Report, 39-45.

Lin, Y.-S. (2011). Fostering Creativity through Education-A Conceptual Framework of Creative Pedagogy. Creative Education, 149-155.

Muhamed, A. (2006). Investigating The Scientific Creativity of Fifth-Grade Students (Unpublished doctoral dissertation). The University of Arizona.

Ratumanan, G. T., dan Laurens, T. (2011). Penilaian Hasil Belajar pada Tingkat Satuan
Pendidikan Edisi ke-2. Surabaya: Unesa University Press.

Slavin, R. E. (2012). Educational Psychology Theory and Practice $10^{\text {th }}$ Edition. New Jersey: Pearson Education, Inc.

Thiagarajan, Sivasailam. (1974). Instructional Development for Training Teachers of Exceptinal Children: A Sourcebook. Document Resume Indiana University. Bloomington 